\title{
ナノテク材料の現状と将来を見つめる
}

\author{
Now and Future in Nanomaterials
}

ナノテク材料研究会

近年，IC技術に代表される各種電子デバイスの小型化， 高性能化の速度は目覚しいものがありこれれらレクトロ ニクス実装の分野においてナノテク材料の果たす役割は最 近急速に大きくなりつつある。例えばサブミクロンオー ダーの電子材料を考えた場合, 従来のマクロな材料を対象 としたときには問題とされなかったサブナノからサブミク ロン領域の性質が材料全体の諸特性に反映されることにな る。したがって微小領域での化学組成の均一化や微細構造 の制御技術を確立し, かつ電気特性を向上させる必要があ る。また，このようなトップダウン手法によるナノテク技 術を確立するばかりではなく, ナノカーボンやフラーレン を利用した材料や自己組織化薄膜などのような, 分子から のボトムアップ手法によって得られた材料のエレクトロニ クス実装としての実用性や用途についても検討していく必 要がある。

そこで本研究会ではますます要求されているナノテク材 料について技術的な発展や問題点について検討するととも に, まだ学問的領域であるボトムアップ手法で作られたナ ノ材料の新規電子材料としての可能性や実用性についても 模索することを主眼に置いた。活動計画としては年間 4 5 回程度の会合を開き,ナノテク材料に関する年間 $3 \sim 4$ 回の 公開講演会を企画する。この講演会によって研究会の調 查・研究活動を行うばかりではなく, 学会員への情報提供 を図る。

なお, 第 1 回目の講演会を次の内容で開催した。

主題：「エレクトロニクスにおけるナノコンポジットの 最新動向」

日時：2005年7月 1 日（金）

場所：キャンパス・イノベーションセンター国際会議室

（† 108-0023 東京都港区芝浦 3-3-6, http://www. mext.go.jp/b_menu/houdou/15/07/03073103/004.pdf)
講演 :

・ポリマークレイナノコンポジット材料の開発 臼杵有光（豊田中研）

・分子ハイブリッド材料のフレキシブルプリント 基板への応用 合田秀樹（荒川化学）

・ナノフィラー含有ポリマーアロイの物性とダイ

ボンディングフィルムへの応用

稲田禎一（日立化成）

第 2 回は, 10 月 26 日のエレクトロニクス実装学会材料技 術委員会の公開講演会の一部としてナノプリンティング関 連の 3 つの講演を行う予定である。

ナノテクと名がつく講演会や研究会はこのところ急激に 増加している。どの講演会に行っても毎回同じような講演 者が同じことを話されていることもあるようである。本研 究会では大学の教員の講演だけに限らず, エレクトロニク 又実装学会らしく企業の研究者が日ごろ考えていることや 技術上の問題点やその解決法などを許される限り話してい ただいて, 他のナノテク関連講演会や勉強会にはない特徵 を出して行きたいと考えている。多くの会員が本講演会に ご参加・ご協力していただけることをお願い申し上げる。

文責 ·横澤 勉 / 神奈川大学 (2005.6.6-受理)

\section{主查：横澤 勉}

神奈川大学工学部応用化学科教授

E-mail: yokozt01@kanagawa-u.ac.jp

幹事: 大月敏敬

JSR 株式会社筑波研究所

E-mail: toshihiro_ootsuki@jsr.co.jp 